\title{
OBLICZA PRZYRODY W WYOBRAŻENIACH DAWNYCH SŁOWIAN
}

\section{IMAGES OF NATURE IN THE IDEAS OF ANCIENT SLAVS}

\author{
Kamila Musiat ${ }^{1(\mathrm{~A}, \mathrm{~B}, \mathrm{C}, \mathrm{D}, \mathrm{E}, \mathrm{F}, \mathrm{G})}$
}

${ }^{1}$ Instytut Zootechniki, Państwowy Instytut Badawczy, Zakład Systemów i Środowiska Produkcji

Musiał, K. (2018). Oblicza przyrody w wyobrażeniach dawnych Słowian. Rozprawy Społeczne, 12(4), $15-21$.

https://doi.org/10.29316/rs.2018.32

Wkład autorów:

A. Zaplanowanie badań

B. Zebranie danych

C. Dane - analiza i statystyki

D. Interpretacja danych

E. Przygotowanie artykułu

F. Wyszukiwanie i analiza

literatury

G. Zebranie funduszy

\begin{abstract}
Streszczenie
Opracowanie dotyczy niektórych wierzeń i przesądów dawnych Słowian, związanych z roślinami i zwierzętami. Celem analizy było przedstawienie gatunków, które pojawiły się w wybranych mitach i legendach dotyczących dawnych Słowian. Reprezentowały one dwie strony natury: realną/racjonalną oraz wyimaginowaną/nieracjonalną. Stąd zasób wiedzy, jak również ignorancji, zastanej w tamtych czasach, został przetłumaczony na zmitologizowane teksty, z których część przetrwała w kulturze do dnia dzisiejszego. Racjonalna strona natury reprezentowana była przez rolnictwo, ale także rośliny o znaczeniu leczniczym i kosmetycznym. Druga strona przedstawiała natomiast lęki i niepokoje ówczesnych ludzi, które były używane w określonych często celach, np. w guślarstwie czy magii miłosnej. W takich podaniach rośliny stanowiły często centralne motywy, a zwierzęta niejako umiejscawiano $\mathrm{w}$ tle, zaś ich rola sprowadzała się jedynie do towarzyszenia tym pierwszym. Jednakże to właśnie zwierzęta wydają się bardziej tajemnicze i obdarzone większymi mocami. W środku tych dwóch sfer znajdowało się „drzewo kosmiczne”, tzw. axis mundi, które używane było przy opisie uniwersum. Ze względu na przewage specyficznych warunków naturalnych, łatwo można sobie wyobrazić że motyw drzewa stanowił najłatwiejszy do odczytania symbol świata, poprzez który obserwowano śmierć i odradzanie się natury, a drzewo stało gdzieś pomiędzy tymi sferami, penetrując poszczególne wymiary.
\end{abstract}

Słowa kluczowe: dwie strony natury, rośliny i zwierzęta, dawni Słowianie, mity i tradycje

\section{Summary}

This paper is dedicated to some of the beliefs and customs of the ancient Slavic folk related to plants and animals. The aim of the study was to describe some species, which appeared in the selected myths and legends concerning Slavs. They usually represented two spheres of nature: $\mathrm{real} / \mathrm{rational}$ and imaginary/irrational. Hence, the store of knowledge and ignorance that existed in those times was translated into a particular, often mythologized texts, some of which survived in the culture until this day. The rational side of nature was represented by agriculture, but also some medicinal and cosmetic plants. The other side was expressed by the fears and anxieties of people from those times, and was used for various purposes, such as witchcraft and love magic. In such tales, it is plants that usually make the central motifs, and animals are captured in the background, only accompanying them. Yet, the latter seem more mysterious and endowed with greater powers. In the middle of those spheres, there is located a theme of the tree, which is also known as a "space tree" or axis mundi, used for describing the universe. Due to the prevailing specific natural conditions, it is easy to imagine that such a motif was the most readable symbol of the world through which death and rebirth of nature were observed, standing somewhere between these spheres and penetrating the particular dimensions.

Keywords: two sides of nature, plants and animals, ancient Slavs, myths and traditions
Tabele: 0

Literatura: 35

Otrzymano: marzec 2018

Zaakceptowano: czerwiec 2018 zjawisk wytłumaczalnych w sposób racjonalny, jak np. powtarzalność pór roku, jak również takich które nie mieściły się w systemie rozumowania ówczesnych ludów, a wzbudzały jedynie zdziwienie lub strach (Mitologie Świata, Słowianie..., 2007). Do tych pierwszych należało rolnictwo, od zawsze uzależnione od warunków klimatycznych i atmosferycznych, dla obłaskawienia których oddawano cześć matce ziemi, reprezentowanej przez święte gaje i cieki wodne. Świadczy to o tym, że religia Prasłowian miała cechy kultu uosobionej przyrody,

Adres korespondencyjny: Kamila Musiał, Instytut Zootechniki, Państwowy Instytut Badawczy, Zakład Systemów i Środowiska Produkcji, ul. Krakowska 1, 32-083 Balice, tel.: 666081299 e-mail: kamila.musial@izoo.krakow.pl, ORCID: https://orcid.org/0000-0002-6713-341X Copyright by: Państwowa Szkoła Wyższa im. Papieża Jana Pawła II w Białej Podlaskiej, Kamila Musiał

Czasopismo Open Access, wszystkie artykuły udostępniane są na mocy licencji Creative Commons Uznanie autorstwa-użycie niekomercyjne-na tych samych warunkach 4.0 Międzynarodowe (CC BY-NC-SA 4.0, http://creativecommons.org/licenses/by-nc-sa/4.0/). 
co było źródłem powstawania rozmaitych mitów i tradycji, których motywem przewodnim były elementy świata ożywionego, reprezentowane przez rośliny i zwierzęta.

Nauki przyrodnicze i humanistyczne, pomimo że zajmują się poznawaniem i opisywaniem świata na odmienne sposoby, od wieków połączone były silnymi więzami. Takie zespolenie znakomicie wpisuje się w obszar aktywności szeroko rozumianej myśli społecznej, wobec czego podobne zagadnienia przedstawiane były w różnych formach (Chmiel, Derewiecki, 2017; Musiał, 2017). Istotne wydają się tu zwłaszcza kwestie dotyczące wiedzy ludowej o roślinach i zwierzętach oraz ich relacjach z człowiekiem (Zając, 2000). Zagadnienia mitu od dawna stanowiły niewyczerpane rezerwy dla jednej z płaszczyzn nauk społecznych, a zainteresowanie taką tematyką stało się szczególnie wyraźne w drugiej połowie XX wieku i w pewnym sensie obserwowane jest do dziś. Stoi za tym teza, że o ile wcześniej mit pełnił istotne funkcje w społeczeństwach dawnych oraz prymitywnych, w ostatnich latach zaszły pewne próby jego rewaloryzacji, zmierzające do przyznania mu istotnego miejsca również w kulturze współczesnej. Argumentacja, z jaką w związku z tym można się spotkać, bywa rozmaita. Różne są także sposoby rozumienia pojęcia „mitu”, który zazwyczaj charakteryzowany jest jako opowieść nieznanego pochodzenia, mająca służyć objaśnieniu pewnych zwyczajów, wierzeń lub zjawisk naturalnych (Kaniowska, 1985; Kopaliński, 1997; Musiał, 2016; Niżnik, 1978).

Jedną z pierwszych osób dostarczających informacji o Słowianach, był w V wieku p.n.e. grecki historyk, Herodot z Halikarnasu, który opisał rejon położony na północ od Morza Czarnego, zamieszkiwany przez ludy utrzymujące się głównie z rolnictwa. Politeistyczna religia ówczesnych Słowian zachowała ścisłe związki właśnie z ich rolniczym trybem życia oraz obserwacjami przyrody. Najważniejszymi postaciami tych wierzeń byli nieliczni bogowie, występujący pod wieloma imionami, którzy pełnili kilka zasadniczych funkcji. Jednak ukształtowanie się tego panteonu oraz zorganizowanego zespołu wierzeń osnutych wokół bóstw i mitów, mogło pojawić się dosyć późno, na przykład dopiero w początkowych fazach średniowiecza. Wcześniejsze przekonania religijne sprowadzały się zaś głównie do demonologii i fascynacji zjawiskami przyrody. Jednakże, również ludzie żyjący w wiekach późniejszych, niejako odziedziczyli po przodkach różnego rodzaju lęki przed bardziej lub mniej znanymi siłami zła oraz różnymi mitycznymi postaciami demonów, które ocalały z zapomnianego, ale niegdyś zwartego sytemu wierzeń słowiańskich. Dlatego też kultura ludowa, będąca udziałem nie tylko społeczności chłopskiej była swoistą kulturą lęku. W tym obszarze ludzkich obaw na pierwszym planie sytuowała się magia, z którą wiązały się różne zabiegi, których celem było zapewnienie urodzaju i zdrowia zwierząt domowych oraz płodności pól
(Bylina, 1990; Kowalik, 2004; Mitologie Świata, Słowianie..., 2007; Skrok, 2006).

W pracy podjęto próbę wyszczególnienia i scharakteryzowania gatunków roślin i zwierząt, wymienianych w wybranych mitach i podaniach dotyczących Prasłowian. Gatunki te ujęte zostały w odrębnych zbiorach, reprezentujących dwie sfery osadzone w przyrodzie, realną/racjonalną oraz nieracjonalną/niezobiektywizowaną.

\section{Koncepcja pracy i jej zakres}

Pozyskanie wiedzy na temat postrzegania i rozpoznawania roślin oraz zwierząt w różnych okresach przez lud, zawsze było trudnym przedmiotem do zbadania. Często uważa się, że to zwierzęta mocniej opanowały wyobraźnię człowieka, jako bardziej tajemnicze, a przez to ekscytujące, częściej przypisywano im także kontakty z zaświatami. Rośliny z kolei analizowano w kontekście tego „co lud wie” np. o roślinach użytecznych i szkodliwych, jak je odróżnia i nazywa, jakie przypisuje im własności pospolite, lekarskie i guślarskie oraz do czego i w jaki sposób używa. Sporna wciąż pozostaje także kwestia odnośnie tego, czy wyobrażenia ludowe o nadprzyrodzonych właściwościach pewnych roślin i zwierząt są pierwotne, tzn. sięgające czasów pogańskich, czy też zostały nabyte później, a więc po przyjęciu chrztu przez Polskę. Do dzisiaj zachowało się bardzo niewiele świadectw mitycznego obrazu świata Prasłowian, w porównaniu choćby do dobrze znanej także w Polsce mitologii greckiej czy rzymskiej. Wynika to w dużej mierze z tego, że wyznawcy przedchrześcijańskiej religii nie znali pisma, przez co nie mogli utrwalić w czasie swoich wierzeń. Jednakże według istniejących źródeł, w okresie poprzedzającym przyjęcie chrześcijaństwa wiele roślin i zwierząt było poświęconych różnym bóstwom, tym samym stanowiły one elementy kultu obecnie w dużej mierze zapomnianego na ziemiach polskich (Rokossowska, 1889; Rostafiński, 1895; Gieysztor, 1982; Sztych, 2008; Bobrowski, Wrona, 2017).

Opracowanie ma charakter przeglądowy i w głównej mierze dotyczy ukazania dualizmu natury w oczach dawnych Słowian. Racjonalność przyrody, tzn. przypisanie jej pewnych własności, dzięki którym poddaje się ona badaniom jest podstawowym założeniem filozofii przyrody i nauk empirycznych (Heller, 2004). Zatem tylko wówczas jest sens zwracać się z racjonalnymi pytaniami do przyrody, gdy oczekuje się, że udzieli ona racjonalnych odpowiedzi. Jednak według różnych badaczy dawni Słowianie często nie poszukiwali logicznych reakcji na pewne zjawiska naturalnie zachodzące w przyrodzie, a kierowali się intuicją czy metafizycznymi odczuciami, generującymi powstawanie różnego typu przesądów oraz uprzedzeń. Jako, że w mitach słowiańskich natura reprezentowana była przez różne gatunki roślin i zwierząt, dokonano próby ich identyfikacji i stanu rozpoznawalności. Odnośnie roślin skupiono się na wybranych zagadnieniach, 
w nawiązaniu do zaproponowanych przez Typek i Kujawską (2014), gdzie za racjonalne oblicze przyrody przyjęto ich praktyczne zastosowanie w życiu codziennym, a zatem w rolnictwie, służących za pożywienie, ale również jako: środki lecznicze, kosmetyczne oraz trucizny. Nieracjonalna część natury, wyobrażana była przez lęki i obawy ówczesnych ludzi przed tym co niezrozumiałe, a w tym celu używane były różne gatunki ziół, którym przypisywano właściwości czarodziejskie, guślarskie lub służące tzw. magii miłosnej. Zwierzęta ujęte zostały niejako na drugim planie, jako towarzyszące roślinom w tego typu podaniach.

\section{Przyroda w mitach i tradycji dawnych Słowian}

Przyroda o dwóch obliczach reprezentowała to co znane, zrozumiałe, jak również wyimaginowane, dziś ujmowane jako nieracjonalne. Pierwsza forma reprezentowana była przez sferę powierzchowną, dobrze widoczną i namacalną, jak wszechobecne lasy oraz praktyczne kwestie mające zabezpieczyć byt, a zatem dotyczące uprawy ziemi i urodzaju. Druga jej postać wiązała się z istnieniem domeny magicznej, nie widocznej na co dzień a osadzonej równolegle do warstwy realnej. Chętnie umiejscawiano ją daleko od oczu żyjących, pośród mało dostępnych borów i mokradeł, gdzie leżała mityczna kraina umarłych (ryc. 1).

Podobnie jak inne ludy żyjące na średnich szerokościach geograficznych, Prasłowianie przy opisie wszechświata najczęściej posługiwali się motywem drzewa. Badacze nazwali je „drzewem kosmicznym", ponieważ umiejscawiane było pomiędzy obydwiema sferami i przenikało poszczególne wymiary. Ze względu na panujące warunki przyrodnicze, łatwo sobie wyobrazić, że było ono centralnym motywem i najbardziej czytelnym symbolem uniwersum, za pośrednictwem którego obserwowano obumieranie i odradzanie się natury. Drzewo stanowiło także swoiste axis mundi, a więc oś świata podpierającą kosmos, a jednocześnie przenikało wszystkie sfery wszechświata, przez co reprezentowało boską obecność i stanowiło przedmiot czci. Wiązało się to $\mathrm{z}$ wiarą, że dorodne drzewa tkwią korzeniami w podziemiach, gdzie rozpościerała się kraina zmarłych Nawia, władana przez boga piekieł Welesa i pilnowana przez węże, a koronami sięgają niebios będących miejscem bytowania boga Swaroga. Jedna $\mathrm{z}$ wersji mitu podaje, że drzewo takie wraz z praoceanem istniało od zawsze, było ciężkie i wysokie, a w jego koronie mieszkał kur, który miał zapiać tylko raz, wieszcząc koniec świata. Inne podania mówią o tym, że był to orzeł lub kruk. Kult drzewa był rozpowszechniony u wszystkich ludów słowiańskich, a największym szacunkiem otaczane były dęby i lipy, stanowiące ważne komponenty lasów grądowych, porastających olbrzymie połacie terenów dzisiejszej Polski (Gieysztor, 1982; Impelluso, 2006; Mitologie Świata, Słowianie .., 2007; Bobrowski, Wrona, 2017).

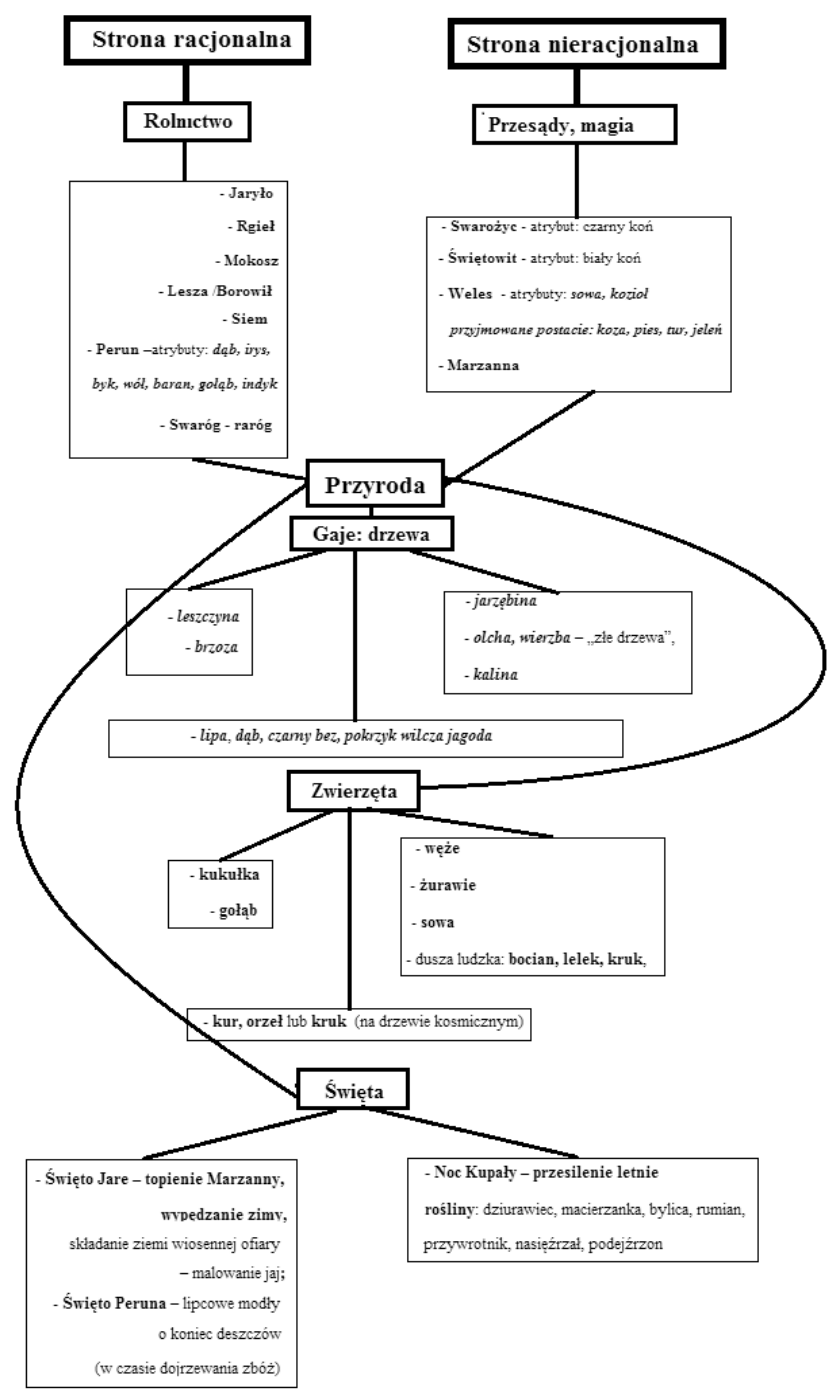

Rycina 1. Zwierzęta i rośliny jako uosobienie dwóch sfer przyrody

Źródło: opracowanie własne na podstawie źródeł literaturowych (Białczyński, 1993; Bobrowski i Wrona, 2017; Gieysztor, 1982; Kotarska, 1997; Lurker, 1994; Łowmiański, 1986; Mitologie Świata - Słowianie, 2007; Storl, 2009).

Obraz drzewa najczęściej utożsamiany był z dębem (Quercus sp.), jednym z najważniejszych, a zarazem najbardziej długowiecznych gatunków leśnych strefy umiarkowanej. W oczach dawnych Słowian wyróżniał się na tle innych drzew masywnym pniem, rozłożystymi gałęziami, silnymi korzeniami, bujnymi liśćmi oraz charakterystycznymi owocami, w postaci żołędzi. Sprawiało to, że dąb uosabiał siłę i męskość, reprezentując sferę namacalną przyrody. Jako drzewo mężczyzn był symbolem płodności, miał także duży wpływ na rozmnażanie się zwierząt, przez co pasterze zganiali pod dęby swoje stada owiec (Kluk, 1802; Marczewska, 2002; Ziółkowska, 1988).

W tradycji słowiańskiej dąb był poświęcony, najważniejszemu bóstwu, władcy ognia i grzmotów, jakim był Perun i stanowił jeden z najważniejszych 
jego atrybutów. Perun oddziaływał na cała przyrodę, zsyłając burzę i ogień z błyskawic, a dęby jako drzewa wysokie dość często były rażone przez pioruny, co właśnie nadawało im znaczenia sakralnego i symbolizowało duchowy wymiar relacji człowieka do przyrody. Świętość dębu nakazywała jego ochronę, a uszkodzenie go narażało człowieka na zemstę bogów, przez co nie wolno było ścinać tych drzew, a spłonąć mogły jedynie od ognia posłanego przez boga. Dąb był również uważany za drzewo kosmiczne, umożliwiające nawiązanie kontaktu $\mathrm{z}$ niebem i jego istotami, a liście i drewno służyły jako środek zapobiegający czarom (Lurker, 1994; Rostafiński, 1895; Vulcanescu, 1979).

Antynomicznie do dębu, drugim świętym drzewem była lipa (Tilia sp.), która także miała wpływać na płodność, tyle że uważano ją za drzewo żeńskie. W dawnych wiekach, kiedy miejscem religijnych praktyk były święte gaje, lipy wyznaczały przestrzeń która służyła pogańskim bóstwom za świątynie, dając ochronę przed demonami, jak również była miejscem odprawiania rytuałów czy różnych obrzędów (Kotarska, 1997). Poprzez lipę bóstwa objawiały swoją dobroć, życzliwość, łagodność oraz szczodrość, ponadto uważano ją za drzewo dobrze wpływające na los człowieka. Ochronę domostwa przeciw demonom można było zapewnić za pomocą gałązek lipowych, które były wtykane w ściany, dachy i płoty. Z kolei wianki splecione z gałązek lipowych, miały zapewnić domostwu spokój, a gdy okadzano nimi dom przed burzą, wówczas pioruny i deszcze miały omijać zagrodę (Ziółkowska, 1988). W wierzeniach Słowian lipa była drzewem poświęconym różnym boginiom i nimfom, ale także chroniącym święte źródła. Ponadto wyznaczała miejsca do odprawiania sądów oraz była miejscem, gdzie grzebano kobiety. Drzewo to było również wykorzystywane we wróżbach oraz praktykach magicznych.

Z naturą powiązany był wyraźnie kult kilku bóstw mitologicznych, na co przykładem był Jaryło, słoneczny bóg płodnej przyrody, spleciony ze światem roślinnym, który ożywiany był przez promienie słoneczne i im zawdzięczał bujną wegetację. Przez to był on opiekunem rolników, który „otwierał" wiosnę i inicjował pierwsze prace polowe, tym samym reprezentując racjonalną stronę natury. Ponadto w panteonie bóstw słowiańskich znalazł się również bóg polnych urodzajów o imieniu Rgiet jak również Mokosz będąca boginią związaną z kultem matki ziemi, przez co kojarzono ją z deszczem, urodzajem i płodnością. Być może dzisiejsze święcenie potraw podczas Wielkanocy jest wręcz zmodyfikowaną tradycją składania wiosennej ofiary owej bogince ziemi. Ponadto, według Białczyńskiego (1993), do plejady owych bóstw należała także Lesza, będąca boginią lasów i borów, a zarazem żeńskim odpowiednikiem Borowiła. Z kolei Siem to prastara matka ziemia, podobnie jak Mokosz utożsamiana z płodnością i uprawą roli.

Mający siedzibę w koronie dębu Perun, posiadał atrybuty w postaci zwierząt gospodarskich będą- cych nosicielami jego siły, były to: byk, wół, baran, indyk, ale też gołębie. Do jego roślinnych atrybutów zaliczano dębowe żołędzie oraz gatunek kosaćca (Iris germanica), zwany kwiatem piorunowym lub też perunowym. Wreszcie ważną rolę odgrywał Swaróg, czyli bóg nieba, a według innych hipotez także boski kowal i stwórca słońca. Sfera niebieska jak już wspomniano, mieściła się w koronie drzewa, gdzie ów ojciec bogów przebywał bezczynnie, przyglądając się ziemi. Jego zwierzęciem był drapieżny ptak z rodziny sokołowatych zwany rarogiem, niegdyś bardzo drogi i używany do polowań. Wartym odnotowania jest, że o ile w Europie Środkowej owi bogowie zostali dosyć szybko zapomniani, na Litwie, której chrzest odbył się późno, jeszcze w XVII wieku funkcjonowały różne zwyczaje związane $\mathrm{z}$ takimi pogańskimi wierzeniami. Miały one zapewniać płodność ziemi i korzystne zmiany pogody, m.in. kukułce przypisywano zapowiadanie wiosny i deszczu, ponadto jako przynętę dla deszczu wieszano skórę baranią, a gołębie stanowiące symbol płodności, należały do magii miłosnej i były objęte zakazem spożycia (Gieysztor, 1982).

Magiczną stronę przyrody reprezentował natomiast ogólnosłowiański kult boga wyroczni $S w a-$ rożyca, którego atrybutem był używany we wróżbach czarny kon. Z kolei Świętowit, będący bóstwem wojny ale i światła, posiadał różne magiczne moce, a jego atrybutem był biały wierzchowiec. Weles to natomiast bóg magii, przysięgi i zaświatów, także bóg bydła. Jego kult wywodził się prawdopodobnie z kultu bydła rogatego, ale mógł przyjmować także inne zwierzęce postacie, m.in.: kozy, psa, tura lub jelenia. Do jego atrybutów należały ponadto sowa oraz kozioł. Córką Welesa była Marzanna, nazywana boginką śmierci i zimy. Według wierzeń prastarych Słowian dusze ludzkie po śmierci przenosiły się do Wyraju, krainy duchów oraz ptaków. Wiązało się to z faktem, że Słowianie wyobrażali sobie duszę ludzką, właśnie jako ptaka, ponieważ zwierzęta te od zawsze onieśmielały ludzi swoimi zdolnościami do lotu. Dumne żurawie były np. przewodnikami dusz do Wyraju. Różne porzekadła wspominają tutaj także o bocianach, lelkach i krukach, będących wcieleniem duszy ludzkiej. Natomiast sowy zwiastowały często śmierć albo inne nieszczęście, ale nie pozbywano ich się $\mathrm{z}$ okolic domostw, z tego względu że żywiąc się myszami, wpływały na regulację wielkości populacji tych gryzoni i zapewniały ochronę plonów (Gieysztor, 1982).

\section{Słowiańskie święta i święte miejsca}

Rośliny, a zwłaszcza ich kwiaty uważane są za najpiękniejsze twory przyrody, od zawsze działały wabiąco na zmysły, przez co towarzyszyły także słowiańskim świętom i uroczystościom. Według Szafera i Szaferowej (1948), przez całe wieki stosunek człowieka do kwiatów był dwoisty, zarówno praktyczny, jak i idealistyczny. Wiele z nich towarzyszyło obrzędom związanym z Nocą Kupały, która 
nazywana była również słowiańskimi dionizjami. Było to święto obchodzone w noc przesilenia letniego na rozległych obszarach Europy Środkowej, ku czci ognia, wody, słońca, księżyca, urodzaju i płodności. Początkowo badacze wywodzili jego nazwę od słowiańskiego bóstwa Kupały, potem zaczęto uważać, że nazwa święta pochodzi od obowiązkowej w czasie tej nocy rytualnej kąpieli. Z obchodami święta wiązało się wrzucanie do ognia i wody zebranych wcześniej kwiatów i ziół, którym przypisywano magiczne moce. Były to m.in.: dziurawiec, rumian, przywrotnik, macierzanka i bylica.

Najważniejszym zielem stosowanym w trakcie tej nocy był dziurawiec zwyczajny (Hypericum perforatum), używany przez dawnych Słowian od niepamiętnych czasów zarówno jako roślina magiczna, jak też lecznicza. Po dziś dzień nazywa się go zielem guślarskim albo świętojańskim, ponieważ czas kwitnienia przypada właśnie na obchodzoną przed wiekami Noc Kupały (Cwener, Sudnik-Wójcikowska, 2012). Według Rostafińskiego (1895), używany był przeciw czarom i gusłom, jak również związane z nim były pewne elementy magii kobiecej, dotyczące wróżenie $\mathrm{z}$ ziela zebranego $\mathrm{w}$ noc letniego przesilenia. Do ochrony domów przed złymi mocami używano natomiast dymu z suszonego dziurawca (Styczyński, 2012).

Innym ważnym gatunkiem roślin związanym z obchodami Nocy Kupały była bylica pospolita (Artemisia vulgaris), którą uważano za roślinę czarodziejską i magiczną. W wiekach późniejszych Marcin z Urzędowa wspominał, że używano jej przy Sobótkach czyniąc ofiarę diabłu. Wokół ognisk odbywały się wówczas tańce, w czasie których ludzie przepasani byli tylko gałązkami bylicy, co miało zapewnić zjednoczenie się z „inną”, magiczną rzeczywistością. Uważana była ponadto za roślinę niewieścią, mającą leczyć z bezpłodności (Rokossowska, 1889; Rostafiński, 1895; Storl, 2009). Była także uważana za szczególnie „drogocenne ziele, gdyż nie rosła przy każdym domu .. używana przeciw złym duchom i czarom, podobnie jak inne rośliny o intensywnym zapachu .. miała też odpędzać złe duchy wywołujące burze" (Gustawicz, 1882, str. 226). Z kolei z przywrotnika (Alchemilla sp.) lud plótł w noc przesilenia wianuszki, które następnie były puszczane na wodę. Ususzone wianki kładziono także na węgle i okadzano nimi całe obejście w celu sprowadzenia deszczu (Gustawicz, 1882). Macierzanka (Thymus sp.) stosowana była jako „zabezpieczenie przed czarami”.. ciało sokiem pomazane było zabezpieczone od jadowitych ukąszeń" (Rostafiński, 1895, str. 42).

W czasie nocy letniego przesilenia szukano również mitycznego, legendarnego kwiatu paproci, który podobnie jak irys, także nazywany był perunowym, a miał kwitnąć tylko w tę najważniejszą w roku noc. Dostępu do niego miały utrudniać różne straszydła, które zwodziły na manowce poszukiwaczy kwiatu, którego odnalezienie miało wróżyć pomyślny los oraz zapewniać bogactwo i dostatek, przez co jego poszukiwania stały się stałym elementem obchodów
Święta Kupały (Mitologie Świata, Słowianie..., 2007). Dodatkowo do powstania legendy o perunowym kwiecie przyczynić się mogły gatunki paproci zwane potocznie „paprociami kwitnącymi”, jak gatunki nasięźrzału (Ophioglossum sp.), czy podejźrzona (Botrychium sp.), których drobne sporonośne liście zebrane w obfite grona na wydłużonych łodygach sprawiają wrażenie gron kwiatowych. Tym samym szukanie i znajdowanie „kwiatu paproci”, choć utrudnione przez ciemność i podmokły grunt, wcale nie było skazane na niepowodzenie.

Według Łowmiańskiego (1986), podanie o kwiecie paproci wywodzi się ze zwyczaju smarowania się przez kobiety liśćmi nasięźrzału w trakcie obchodów święta, co miało w magiczny sposób podnieść ich atrakcyjność. Nasięźrzał pospolity (Ophioglossum vulgatum) był też używany do czarów przez młode dziewczęta, które chciały sobie „zjednać miłość młodziana". W tym celu należało zerwać tą roślinę nago o północy, a w czasie zrywania trzeba było być odwróconym do niej plecami i wypowiedzieć stosowną formułę (Gustawicz, 1882), choć zapewne niewielkie rozmiary rośliny występującej w wysokiej trawie nie ułatwiały tego zadania.

Ważne w kulturze słowiańskiej było także Święto Jare, stanowiące kilkudniowy cykl obrzędowy, związany z zakończeniem zimy i powitaniem wiosny. Zwyczaj ten związany był $\mathrm{z}$ topieniem $\mathrm{Ma}$ rzanny i do dziś jest on po prostu reminiscencją dawnego pogańskiego obrządku, symbolizującego wypędzenie zimy i odradzanie się życia. Kukłę ze słomy obnoszono po wsi a następnie topiono w rzece, a jej szczątki rozrzucano po polach, co miało zapewnić lepsze plony. Święto to Słowianie obchodzili na różne sposoby, nie tylko przez topienie kukły, ale również poprzez malowanie jajek. Miało to wnieść do domostw energię i radość życia oraz zapewnić urodzaj i powodzenie na cały rozpoczynający się wiosną nowy rok wegetacyjny. Niektórzy badacze przypuszczaja, że obyczaj ten mógł zostać przejęty od Celtów (Mitologie Świata, Słowianie..., 2007). Z kolei Święto Peruna to starosłowiańska uroczystość poświęcona jednemu $\mathrm{z}$ głównych bóstw w panteonie. Obchodzone 20 lipca, związane było z modłami o koniec deszczów oraz burz i zejście wód do podziemia, w związku z dojrzewaniem gatunków zbóż (Gieysztor, 1982).

Oprócz tradycyjnie obchodzonych świąt, Słowianie mieli także swoje święte miejsca, usytuowane najczęściej w lasach, w których czczono bogów i odprawiano rytualne obrzędy. Dla mieszkających pośród rozległych lasów plemion słowiańskich, święte gaje były naturalnymi miejscami, które stanowiły skumulowane źródło mocy. Jawiły się one jako nietknięty ludzką ręką skrawek prastarego lasu, a wszystko co się w nim znajdowało: źródła, śródleśne jeziora, duże głazy, czy ogromne stare drzewa, nabierało magicznej mocy (Mitologie Świata, Słowianie..., 2007). Samo słowo „gaj” znaczy tyle co „grodzić”, z czego można by wnioskować, iż były to miejsca niedostępne dla wszystkich. 
Zazwyczaj w centrum świętego gaju rosło stare drzewo, przy czym za siedzibę bóstwa uważany był najstarszy w lesie okaz dębu lub lipy. Towarzyszyły im m.in. brzoza, jarzębina, leszczyna, czarny bez czy pokrzyk wilcza jagoda. Łącznikiem dwóch światów, jasnego i pomyślnego dla ludzi (kwiaty), z ciemnym i wilgotnym, pełnym pułapek światem podziemnym (owoce, wino bzowe), już wedle najstarszych opisów miał być czarny bez (Sambucus nigra). Jego znaczenie demoniczne odnosiło się też do korzeni, będących siedzibą diabła i innych istot, których towarzystwa raczej nie szukano w codziennym życiu, a zwracano się do nich jedynie w sytuacjach zagrożenia. Znany był także zakaz jego ścinania i palenia jego drewnem, a zielone gałązki bzu miały chronić od złych mocy (Gustawicz, 1882; Styczyński, 2012). Niektórzy uważali natomiast, że wyrwanie bzu z korzeniami może wręcz grozić paraliżem (Hodoly, 1882).

Także pokrzyk wilcza jagoda (Atropa belladonna) znajdował się niejako po środku sfery realnej i magicznej. Z jednej strony ta, zawierająca wiele silnych substancji chemicznych roślina, nieraz mylnie opisywana jako mityczna mandragora, używana była dla celów upiększających, jako środek kosmetyczny (Styczyński, 2012). Z drugiej zaś, uważa się ją za bodaj najbardziej czarodziejską i owianą mitami roślinę obszaru Karpat. Nazwa pochodzi od jej domniemanej zdolności do wydawania zduszonego okrzyku lub westchnienia. Także już po przyjęciu chrześcijaństwa Atropa belladonna stosowana była przy rozmaitych „zamawianiach” i „szeptach”, do czego używano ugotowanego korzenia, który następnie dawano do wypicia osobom obłąkanym, czy w konwulsjach, jednak jak się uważa bardziej po to aby chory zmarł, niż w celu jego wyleczenia (Rokossowska, 1889).

Ponadto innym gatunkiem leśnym reprezentującym sferę racjonalną $\mathrm{w}$ przyrodzie była brzoza (Betula sp.). Miała ona przywracać siły witalne, a jej kora była biała i czysta ,jak dusze dziewcząt zmarłych przed zamążpójściem”, przez co podobnie jak lipa była drzewem kobiecym. Podobnie leszczyna (Coryllus sp.), uważana była przez Zachodnich Słowian za drzewo przyjazne dla człowieka. Obok tzw. dobrych drzew, były też drzewa złe, np. olchy (olsza, Alnus sp.) i wierzby (Salix sp.), które wiązano z wilkołakami i wampirami, natomiast jarzębina (Sorbus sp.) służyła do odstraszania złych mocy. Z kolei kalina (Viburnum sp.) była boskim i świętym krzewem, na którym często siadywały mityczne żar-ptaki o ognistych piórach, które obdarzone były magiczną mocą.

Dla Słowian święte gaje były też miejscami, w których składano ofiary bogom, ale również które $\mathrm{z}$ takim zawzięciem były niszczone przez rodzace się później chrześcijaństwo. Według Gieysztora
(1982), kiedy w XV wieku św. Hieronim z Pragi udał się na Litwę, głosząc wiarę chrześcijańską, w jego relacji znaleźć można opis czci oddawanej świętym lasom i wężom. Kiedy w zapale misjonarskim Hieronim pozabijał węże i ściął święte drzewo, okoliczni mieszkańcy poszli na skargę do księcia Witolda, że przybysz zniszczył obiekty ich czci. Fascynacja człowieka gadami, zwłaszcza zaś wężami, ma charakter nie tylko naukowy, ale przede wszystkim właśnie kulturowy. Od wieków inspirowały one ludzką wyobraźnię i w wielu kulturach wąż był symbolem o ogromnej sile i pełniącym różnorodne role. Te „milczące” i beznogie stworzenia, zabijające znacznie większe od siebie ofiary, budziły nie tylko ciekawość, ale i lęk, przez co u wielu ludów prymitywnych, także wśród ludów słowiańskich stanowiły jedne $\mathrm{z}$ najważniejszych świętych zwierząt (Peter, 2014).

\section{Podsumowanie}

Pomimo, że do dnia dzisiejszego w literaturze dotrwało niewiele imion bóstw związanych z mitologią Słowian, a dostępne na ich temat informacje są fragmentaryczne, udało się powiązać z nimi różne gatunki lub rodzaje roślin i zwierząt. Wzmianki o nich oraz opisy odnaleźć można w podaniach i mitach, gdzie stanowią atrybuty bóstw, nadając im określone moce oraz posiadają symboliczne znaczenie w obrzędach ludowych. Rośliny są tam często centralnymi motywami, jak choćby w przypadku podania dotyczącego drzewa kosmicznego, a zwierzęta jedynie im towarzyszą, jednak te drugie wydają się bardziej tajemnicze i obdarzone większymi mocami.

Nasi przodkowie postrzegali naturę w wyraźnie dwoistej formie, zarówno w wymiarze tego co przyroda realnie dawała człowiekowi, głównie w kontekście pożywienia czy środków leczniczych, jak i tego co jedynie było wyobrażone i najczęściej napawało lękiem. Ponadto $\mathrm{w}$ niektórych przypadkach, to co racjonalne i wyimaginowane wydawało się wzajemnie przenikać i uzupełniać. Oczywiste wydaje się, że dawni Słowianie znacznie częściej niż ludzie współcześni używali irracjonalnych argumentów, w związku z upatrywaniem w przyrodzie sił o nadprzyrodzonych mocach. Z kolei wedle obecnie panujących koncepcji, najistotniejszą siłą i cechą człowieka jest rozum, a rozmaite przesądy, uprzedzenia i pozaziemskie ingerencje należy odrzucić. Z drugiej jednak strony w dzisiejszych czasach obserwowane jest zainteresowanie taka tematyką, co bardziej niż jej rzeczywistym przetrwaniem $\mathrm{w}$ formach dotychczas znanych, można tłumaczyć wyrazem pewnej tęsknoty do elementu mitycznego w kulturze. 


\section{Literatura:}

1. Białczyński, C. (1993). Stworze i zdusze, czyli starosłowiańskie boginki i demony. Leksykon. Kraków: Wydawnictwo Kraina Księżyca.

2. Bobrowski, J., Wrona, M. (2017). Mitologia słowiańska. Olszanica: Wydawnictwo BoSZ.

3. Bylina, S. (1990). Magia, czary i kultura ludowa w Polsce XV i XVI w. Odrodzenie i Reformacja w Polsce, 35, 39-52.

4. Chmiel, K., Derewiecki, T. (2017). Zwierzęta towarzyszące aktywności fizycznej dawnych Polaków. Rozprawy Społeczne, 11(3), 71-74. https://doi.org/10.29316/rs.2017.30

5. Cwener, A., Sudnik-Wójcikowska, B. (2012). Rośliny kserotermiczne. Leksykon. Warszawa: Oficyna Wydawnicza Multico.

6. Gieysztor, A. (1982). Mitologia Słowian. Mitologie Świata. Warszawa: Wydawnictwa Artystyczne i Filmowe.

7. Gustawicz, B. (1882). Podania, przesądy, gadki i nazwy ludowe w dziedzinie przyrody. Zbiór Wiadomości do Antropologii Krajowej, 6, 218-299.

8. Heller, M. (2004). Filozofia przyrody. Zarys historyczny. Kraków: Wydawnictwo Znak.

9. Hodoly, L. (1882). Mały przyczynek do wierzeń i podań ludowych o zwierzętach i roślinach. Zbiór Wiadomości do Antropologii Krajowej, 6, 320.

10. Impelluso, L. (2006). Natura i jej symbole: rośliny i zwierzęta, (tłum. H. Cieśla). Warszawa: Wydawnictwo Arkady.

11. Kaniowska, K. (1985). Dychotomia natura-kultura, jako szczególny problem etnologii. Etnografia Polska, 29(1), 27.

12. Kluk, K. (1802). O roślinach, ich utrzymaniu, rozmnożeniu i zażyciu. Roślin potrzebnych, pożytecznych, wygodnych, osobliwie krajowych, albo które w kraju użyteczne bydź moga. Warszawa.

13. Kopaliński, W. (1997). Słownik mitów i tradycji kultury. Kraków: Państwowe Wydawnictwo Naukowe.

14. Kotarska, J. (1997). Co lipie do wierszów? Drzewa arkadii ziemiańskiej. W: A. Martuszewska (red.), Literacka symbolika roślin (s. 6-13), Gdańsk.

15. Kowalik, A. (2004). Kosmologia dawnych Słowian. Prolegomena do teologii politycznej dawnych Słowian. Kraków: Zakład Wydawniczy Nemos.

16. Lurker, M. (1994). Przesłanie symboli w mitach, kulturach i religiach, (tłum. R. Wojnakowski). Kraków: Wydawnictwo Znak.

17. Łowmiański, H. (1986). Religia Słowian i jej upadek. Warszawa: Państwowe Wydawnictwo Naukowe.

18. Marczewska, M. (2002). Drzewa w języku i w kulturze. Kielce: Wydawnictwo Akademii Świętokrzyskiej.

19. Mitka, J. (2000). Krajobraz kulturowy jako wyraz harmonii między człowiekiem a przyrodą. W: B. Zemanek (red.), Przyroda - Nauka - Kultura (s. 157-164). Kraków: Instytut Botaniki im. W. Szafera PAN.

20. Mitologie Świata - Słowianie. (2007). Rzeczpospolita. Redaktor prowadzący - G. Skibicka. Kraków: Drukarnia Narodowa SA.

21. Musiał, K. (2016). Drzewa, krzewy, pnącza i rośliny zielne w mitologii greckiej. Aura, 12, 21-24.

22. Musiał, K. (2017). Rośliny lecznicze w najwcześniejszych dokumentach wiedzy medycznej. Rozprawy Społeczne, 11(4), 56-63. https://doi.org/10.29316/rs.2017.39

23. Niżnik, J. (1978). Mit jako kategoria metodologiczna. Kultura i Społeczeństwo, 3, 163.

24. Peter, E. (2014). Gady - fakty i mity. Wiadomości Zootechniczne, 50(1), 92-99.

25. Rokossowska, Z. (1889). O świecie roślinnym wyobrażenia, wierzenia i podania ludu ruskiego na Wołyniu. Zbiór Wiadomości do Antropologii Krajowej, 13, 170-80.

26. Rostafiński, J. (1895). Zielnik czarodziejski, to jest zbiór przesądów o roślinach. Zbiór Wiadomości do Antropologii Krajowej, 18, 1, 42-43.

27. Skrok, Z. (2006). Słowiańska moc czyli o niezwykłym wkroczeniu naszych przodków na europejskq arenę. Warszawa: Wydawnictwo Iskry.

28. Storl, W-D. (2009). Zioła lecznicze i magiczne. Białystok: Wydawnictwo Studio Astropsychologii.

29. Styczyński, M. (2012). Zielnik podróżny. Rośliny w tradycji Karpat i Bałkanów. Krosno: Wydawnictwo Ruthenus.

30. Szafer, W., Szaferowa, J. (1948). Kwiaty w naturze i sztuce. Warszawa: Spółdzielnia Wydawnicza Wiedza.

31. Sztych, D. (2008). Zwierzęta gospodarskie w polskiej kulturze ludowej. Wiadomości Zootechniczne, 46(2), 39-47.

32. Typek, J., Kujawska, M. (2014). Rośliny w wierzeniach ludowych w Słowniku wierzeń i zwyczajów słowiańskich - niedokończone dzieło Adama Fischera. Etnobiologia Polska, 4, 89-96.

33. Vulcanescu, R. (1979). Kolumna niebios. Warszawa: Ludowa Spółdzielnia Wydawnicza.

34. Zając, A. (2000). Humanistyczne aspekty badań przyrodniczych. W: B. Zemanek (red.), Przyroda - Nauka - Kultura (s. 13-20). Kraków: Instytut Botaniki im. W. Szafera PAN.

35. Ziółkowska, M. (1983). Gawędy o drzewach, Warszawa: Wydawnictwo LW. 